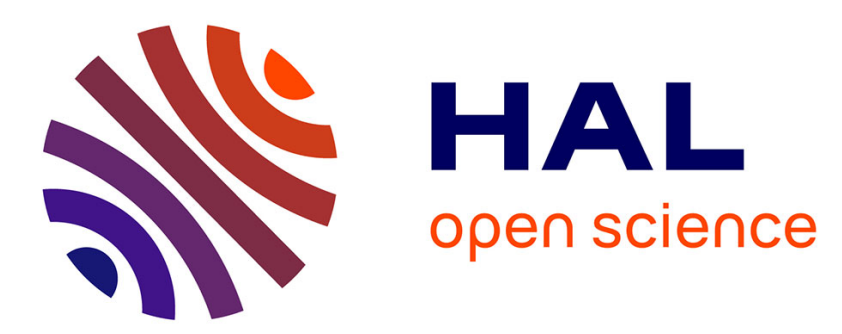

\title{
Parameter analysis of PEM fuel cell hysteresis effects for transient load use
}

\author{
R. Talj, T. Azib, O. Béthoux, G. Remy, C. Marchand, E. Berthelot
}

\section{To cite this version:}

R. Talj, T. Azib, O. Béthoux, G. Remy, C. Marchand, et al.. Parameter analysis of PEM fuel cell hysteresis effects for transient load use. European Physical Journal: Applied Physics, 2011, 54 (2), pp.23410. 10.1051/epjap/2011100266 . hal-00698843

\section{HAL Id: hal-00698843 \\ https://hal.science/hal-00698843}

Submitted on 18 May 2012

HAL is a multi-disciplinary open access archive for the deposit and dissemination of scientific research documents, whether they are published or not. The documents may come from teaching and research institutions in France or abroad, or from public or private research centers.
L'archive ouverte pluridisciplinaire HAL, est destinée au dépôt et à la diffusion de documents scientifiques de niveau recherche, publiés ou non, émanant des établissements d'enseignement et de recherche français ou étrangers, des laboratoires publics ou privés. 


\title{
PARAMETER ANALYSIS OF PEM FUEL CELL HYSTERESIS EFFECTS FOR TRANSIENT LOAD USE
}

\author{
R. Talj, T. Azib, O. Béthoux, G. Remy, C. Marchand, E. Berthelot \\ Laboratoire de Génie Electrique de Paris (LGEP) / SPEE-Labs, CNRS UMR 8507; SUPELEC; Université Pierre et Marie \\ Curie P6; Université Paris 11; 11 rue Joliot Curie, Plateau de Moulon, F 91192 Gif-sur -Yvette CEDEX
}

Keywords: Fuel cell, hysteresis effect, dynamical model, oxidant starvation.

\begin{abstract}
This paper focuses on the hysteresis effect of the polarization characteristics of a polymer electrolyte membrane fuel cell (PEMFC), mainly due to the compressor-air supply system dynamics. Indeed in PEMFC/Ultracapacitor hybrid vehicles, fuel cells can be used to supply the low frequencies of the power demand only. First, the different parts of a FC system are described and modelled in order to analyse the transient stack performance decrease and to identify its main influential factors for automotive applications. Then, apart from humidity and temperature variations, each phenomenon is dynamically described, leading to a complete mathematical model based on macroscopic component parameters. Thus, an analytical model based on this set of equations enables us to draw the static voltage versus current FC characteristics. Furthermore, the hysteresis effect on the V-I curve, which still occurs during low dynamic responses, is shown while temperature and humidity are kept constant. Finally, dynamic responses of the Ballard PEMFC Nexa 1200W generator are analyzed, and detailed experimentation and simulation are carried out for a large magnitude sinusoidal waveform at different frequencies.
\end{abstract}

\section{Introduction}

The proton exchange membrane (PEM) fuel cell has received more attention in recent decades as a clean and efficient power generator for various applications. The new developments are driven by its high energy efficiency, low operating temperature $\left(\sim 80^{\circ} \mathrm{C}\right)$, few moving parts (mechanically robust construction), and low to zero emissions during its operation [1]. In particular, it has been considered one of the most promising alternatives to fossil-based fuel engines for automotive applications [2]. Thus, the PEM fuel cell is an environmentally viable option that is also capable of achieving high power density and high efficiency for long time range applications [3], [4]. Furthermore, PEMFC is a FC technology dedicated to electric loads having erratic use, high transient dynamics and frequent start and stop [5].
Nevertheless, the main disadvantages of fuel cells come from their erratic behaviours due to a high sensitivity of the stack state, low dynamics, high investment and operating costs (due to the presence of platinum in the electrodes) [6], [7].

The dynamic behaviour of a fuel cell is an integral part of the overall stability and performance of the power system. Moreover, many applications require dynamic transient responses faster than those the fuel cell systems can actually encounter. This discrepancy has significant implications on stack performance because of temporal oxidant starvation due to poor air flow dynamics. It leads to low FC efficiency [8],[9] and low lifetime as a result of cathode surface area loss [10-12].

The target applications are electric back-up, portable and automotive devices for instance. In those cases, many hybrid architectures have been suggested using ultra-capacitor banks or battery packs. For such applications, power demand on the FC can be limited to a low-frequency bandwidth around $0.1 \mathrm{~Hz}$ [13], [14] through the simultaneous use of an auxiliary storage electric source dedicated to high transient power. This technique called hybrid power source has, for example, been proposed for automotive applications in which power demand fluctuates suddenly because of speed changes or inclination modifications [17], [18]. Ultracapacitors or lithium-ion batteries are the best candidate technologies for this auxiliary source [19]. To make this hybrid solution technically attractive and economically realistic, optimizing the overall system is a key point. To accomplish this optimization, it is crucial to understand the transient phenomena, to underline their key parameters and to quantify the performance loss.

Figure 1 shows an experimental identification of the $\left(i_{F C}\right)$ characteristic of the $1200 \mathrm{~W}$ Nexa Ballard PEMFC generator.

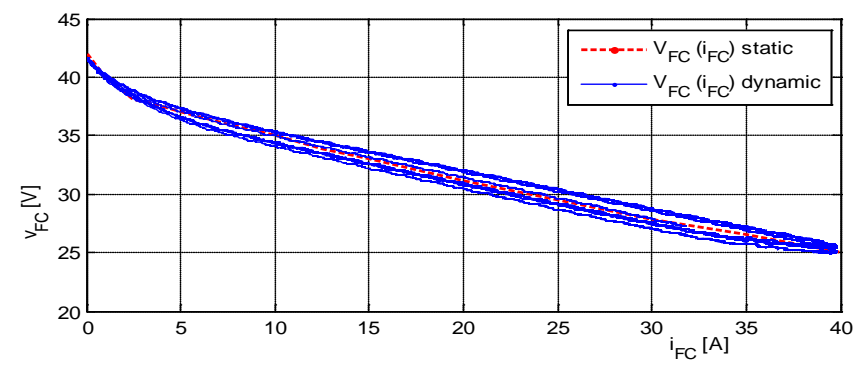

Fig. 1. Voltage vs. Current characteristic of a 1200W Nexa PEMFC at $0.01 \mathrm{~Hz}$ 
It points out that, even at a low frequency $(0.01 \mathrm{~Hz})$, an important parasitic hysteresis V-I curve occurs and has an effect on the electric output of the stack.

The hysteresis effect that occurs in V-I curve for transient load use has been reported in the literature: Many papers have been dedicated to study the mentioned phenomenon, which is due to several reasons. Some studies were focused on the double layer capacitors effect [15], and its interaction with activation losses [35]. Another important reason for hysteresis is the water management in the cells. For instance several works measure the membrane resistance through electrochemical impedance spectroscopy (EIS) and prove that at low power density this impedance is higher when the current increases than when it decreases. Consequently, the variation of the membrane moisture is one of the explanations for the hysteresis effect [39]. Based on a one-dimensional transient FC model other studies investigate a very low frequency hysteresis effect region (around $5 \mathrm{mHz}$ ); this phenomenon derives from poor liquid water at high current densities leading to pore flooding [36][37][38]. YousfiSteiner et al. exploit this remark by performing a polarization curve. They compare the upward current and the downward scans in order to tell whether the FC was dry or flooded [22]. Finally, Turpin et al. report a hysteresis V-I curve at low frequency range due to the slow ( $\mathrm{f} \leq 100 \mathrm{mHz}$ ) and rapid ( $\mathrm{f} \leq 1 \mathrm{~Hz}$ ) reactant diffusion phenomena [16].

However, all these surveys are realized with characterization FC benches where gas flow rates are kept constant. Hence the scope of the present paper is to study another non negligible identified reason of hysteresis, namely the air supply system dynamics [41]. Several reasons motivate this study [16], especially the observed experimental results on a Ballard fuel cell, equipped with a passive humidifier to regulate humidity. Indeed, the obtained results show that, when humidity is controlled, the hysteresis exists and behaves - in some frequency range - in an opposite way compared to the hysteresis due to water accumulation at high current density and dehydration at low current density. This result puts in evidence the effect of the air compressor dynamics. Thus, the phenomenon besides this critical point needs to be well identified and studied deeply; it stands the scope of this paper.

Consequently, the paper focuses on a relevant dynamical model allowing to interpret the transient PEMFC performance degradation during load change. Firstly, the PEMFC principle is explained. Then, the main physical phenomena occurring in the stack are modelled. The next part uses this set of equations. It shows and analyses different simulations permitting to tell apart the major causes and to classify the relevant parameters influencing this V-I hysteresis effect. Finally, an appropriate set of parameters allows to retrieve the V-I curve for a $0.05 \mathrm{~Hz}$ wide magnitude sinusoidal load current.

In following section, PEMFC principles are described in order to explain static model from literature and to introduce the used dynamic model showing hysteresis effect.

\section{PEM Fuel Cell Description}

A PEMFC consists of two electrodes in contact with a membrane separating gas compartments (figure 2). The membrane uses a thin solid polymer and is designed as a proton permeable material and an electronic insulator separating the reactants $\left(\mathrm{H}_{2}\right.$ and $\mathrm{O}_{2}$ /air). The electrodes are constituted of a gas diffusion layer (GDL) and an active layer (AL), both of which have a porous structure, in order to enable both the electrolyte and gases to easily penetrate through it, thus providing a larger triple contact area. This assembly is sandwiched between two current collectors, which deliver the electrons for the external load and include gas channels in which the reactants flow. [20]

The GDL is typically composed of carbon cloth (0.002$0.05 \mathrm{~cm}$ thickness) that provides rigidity and support to the membrane electrode assembly (MEA). It incorporates hydrophobic material that improves water management and electrical properties, and prevents the gas flows from water accumulation. [21]

The AL consists of catalyst particles. Up to now, platinum (pure or alloyed) has been the catalyst material which gives the best electro-catalytic performances. Usually, the platinum catalyst is made of small particles $(2-6 \mathrm{~nm})$ on a support composed of carbon powder, in order to maximize the active surface area. [11]

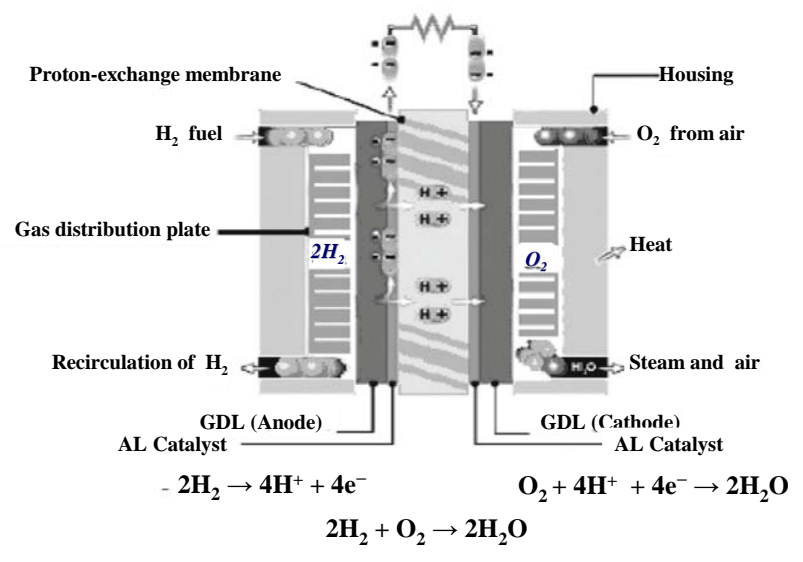

Fig. 2. Illustration of the fuel cell operation [19]

As shown in figure 2, two oxido-reduction couples are involved in fuel cell's electrochemical energy production: Air is fed to the cathodic layer, and hydrogen is fed to the anodic one. The central membrane works as an electrolyte that performs both the functions of transferring $H^{+}$from the anode to the cathode and reactant separation. Besides water, the anode and cathode reactions produce electricity and heat. From a macroscopic view, the fuel cell system is composed of some subsystems which are described in the following section:

\section{- The Proton Exchange Membrane}

- The electro-catalyst layers

- Gas distribution plate and the gaz diffusion layers (GDL) 
- The air supply system is fed by a mechanical system composed of a motor and a compressor [23].

- The hydrogen system is controlled by an electrical valve, and having a much faster dynamic than the mechanical one.

- The cooler to maintain temperature, and the humidifier to control the humidity degree. Humidity and temperature change with a slow dynamics when compared to the other two.

\section{PEM Fuel Cell Model}

PEMFC is a complex multi-physics system which can be described at different scales and can be established for different purposes: to design specific materials or devices [24], to conceive the stack control algorithm [25-27] or to assess the performances of the whole system (FC plants, HEV) [28]. The main objective of this section is to emphasize the key parameters of each subsystem in the global output voltage expression and more precisely on the hysteresis phenomena.

\subsection{Output characteristic model}

The maximum voltage of a cell can be determined from underlying thermodynamics. It refers to the ideal fuel cell voltage (reversible open circuit voltage) given by the Gibbs free energy coefficient divided by the charge flow of the two electrons that are released [29]:

$V_{0}=-\frac{\Delta G_{f}\left(T, p_{i}\right)}{2 F}$

Indeed, the portion of the reaction enthalpy that can be converted to electricity in a fuel cell depends on temperature, and corresponds to Gibbs free energy given by:

$\Delta G_{f}=\Delta H-T \cdot \Delta S$

where $\Delta H$ is the difference between the heats of formation of products and reactants, and $\Delta S$ is the difference between entropies of products and reactants. At temperatures below $100^{\circ} \mathrm{C}, \Delta H$ and $\Delta S$ changes are very limited; they will be considered constant.

Equally important are the changes in Gibbs free energy with reactant pressure and concentration. As the air supply system depends on a relatively slow mechanical part (motocompressor), it is difficult for the partial oxygen pressure to remain constant whatever the load demand. Using thermodynamic arguments (Nernst law), it can be shown that the reversible open circuit voltage can be written as

$V_{0}=-\frac{\Delta G_{f}^{0}(T)}{2 F}+\frac{R T}{2 F} \cdot \ln \left(\frac{p_{\mathrm{H}_{2}} \cdot p_{\mathrm{O}_{2}}^{1 / 2}}{p_{\mathrm{H}_{2} \mathrm{O}}}\right)$

where $\Delta G_{f}^{0}$ is the change in molar Gibbs free energy of formation at standard pressure.

Hence, given the constant values of $\Delta H$ and $\Delta S$ at standardstate conditions $\left(25^{\circ} \mathrm{C}\right.$ and $\left.1 \mathrm{~atm}\right)$, the open circuit voltage $V_{0}$ can be expressed as:
$V_{0}=1.229-8.4610^{-4}(T-298.15)+\frac{R T}{2 F} \cdot \ln \left(p_{H_{2}} \sqrt{p_{O_{2}}}\right)$

In addition the actual voltage that a fuel cell provides is less than this ideal voltage (Eq. (4)) due to various losses taking place in the membrane, at the electrodes and in the anode and cathode sections, as in figure 3 :

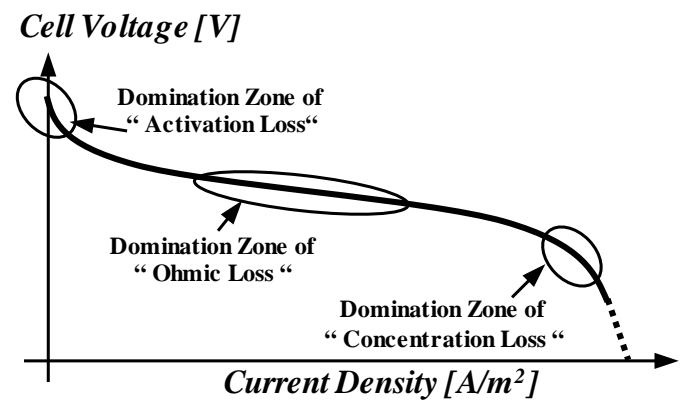

Fig. 3. Fuel Cell voltage versus current characteristic

Namely these irreversibilities are:

- Activation losses owing to the energy used to perform the electrochemical reactions. It is the major loss at low current density.

- Ohmic losses as a result of the flow of protons through the electrolyte and also of the electronic resistance of bipolar plates and various interconnections. They mainly affect the nominal operating region.

- Concentration losses as a consequence of the bulk phase diffusion resistance which reduces the electrode partial pressures compared to the gas inlet ones. They largely influence the high current density zone.

The studied model is the one presented in [30-33], where the output voltage depends essentially on the current density, and the reactant partial pressures. Indeed,

$V_{\text {cell }}=V_{0}-V_{A}-V_{C}-V_{m}-i \cdot R_{I}$

Where $V_{A}$ and $V_{C}$ respectively represent the anodic and cathodic overpotentials, $V_{m}$ represents the ohmic losses, and $R_{I}$ accounts for any interfacial resistance. The latter term being relatively small, it will be neglected in the following study.

\section{- Ohmic losses}

Ohmic losses mostly depend on membrane proton conductivity given by:

$V_{m}=i . L_{m} / \sigma_{m}$

$\sigma_{m}=\left(\varepsilon_{m}-\varepsilon_{m 0}\right)^{q}\left(\frac{\lambda_{H^{+}, 298}^{0}}{1+\delta}\right) \exp \left[\frac{-E_{\mu}}{R}\left(\frac{1}{T}-\frac{1}{298,15}\right)\right] c_{H A, 0} \alpha$

Where, the degree of dissociation $\alpha$ depends on the equilibrium constant $K_{A, C}$ for the protonation reaction as follows: 
$\alpha=\frac{(\lambda+1)-\sqrt{(\lambda+1)^{2}-4 \lambda\left(1-1 / K_{A, C}\right)}}{2\left(\sqrt[1]{\left.-1 / K_{A, C}\right)}\right.}$

Where:

$$
K_{A, C}=K_{A, C, 298} \cdot \exp \left[-\frac{\Delta H^{0}}{R}\left(\frac{1}{T}-\frac{1}{298,15}\right)\right]
$$

The porosity $\varepsilon_{\mathrm{m}}$ of the membrane is related to $\lambda$, the number of water molecules per $-\mathrm{SO}_{3} \mathrm{H}$ group,

$\varepsilon_{m}=\frac{\lambda}{\left(\bar{V}_{M} / \bar{V}_{w}\right)+\lambda}$

Where, $\bar{V}_{M}$ and $\bar{V}_{w}$ are the partial molar volume of the membrane matrix and water respectively. The water molecules $\lambda$ depend on the relative humidity through the Brunauer-Emmett-Teller equation [30].

Consequently, ohmic losses strongly depend both on temperature and membrane humidity. On the contrary, this term does not rely on reactant partial pressures. Hence, once the temperature and relative humidity degree are fixed, which is the case in the simulations and experimental set-up below, the ohmic losses term remains constant and cannot contribute to creating a hysteresis effect.

- Hydrogen oxidation reaction (HOR) and anodic overpotential $V_{A}$

The anodic overpotential is due to activation and concentration losses. It is expressed as follows:

$V_{A}=\frac{R T}{\vec{\alpha}_{A} F} \sinh ^{-1}\left\{\frac{1}{2}\left(\frac{i / i_{A, 0}}{1-i / i_{A, L}}\right)\right\}$.

This expression is the combination of the Butler-Volmer equation, representing the activation losses, and the Nernst equation, representing the concentration losses.

To determine the activation term, the anode exchange current density is calculated using the Arrhenius law as follows:

$i_{A, 0}=\gamma_{M, A}\left(\frac{p_{H_{2}}}{p_{H_{2}, \text { ref }}}\right) \exp \left[-\frac{E_{A, \phi_{0}}}{R}\left(\frac{1}{T}-\frac{1}{T_{\text {ref }}}\right)\right] i_{A, 0, \text { ref }}^{*}$

where, $E_{A, \phi O}$ is the effective activation energy of $i_{A, 0}$. Thus, increasing $i_{A, 0}$ may be accomplished by increasing $\gamma_{M, A}$, temperature, and $\mathrm{H}_{2}$ concentration. It shows that both temperature and partial pressures have a key effect on thermodynamic performance.

Furthermore, to determine the concentration term, the anode limiting current density is calculated with the Fick equation as follows:

$i_{A, L} \equiv\left(\frac{v_{A e^{-}}}{-v_{A, H_{2}}}\right) \frac{F}{R T} P_{H_{2} D} \cdot p_{H_{2} T}$ where $p_{H 2 T}$ is the hydrogen partial pressure in the anode graphite plate, and $P_{H 2 D}$ is the permeability of anodic gas diffusion layer for hydrogen.

The anodic reaction is very fast, particularly when compared with the oxygen reduction reaction (ORR) at the cathode. Furthermore, the anode side is made of a quite pure gas compared to the cathode side where oxygen (an oxidant) is mixed with nitrogen $\left(\mathrm{N}_{2}\right)$. Then, the voltage drop (overpotential) due to the HOR is relatively small, compared to the one due to the ORR.

\section{- Oxygen reduction reaction (ORR) and cathodic overpotential $V_{C}$}

The cathodic overpotential is also caused by the activation and concentration losses. It can be written as follows:

$V_{C}=\frac{R T}{\vec{\alpha}_{C} F} \sinh ^{-1}\left\{\frac{1}{2}\left(\frac{i / i_{C, 0}}{1-i / i_{C, L}}\right)\right\}$

As for the anode, the cathode exchange current density is:

$i_{C, 0}=\gamma_{M, C}\left(\frac{p_{\mathrm{O}_{2}}}{p_{\mathrm{O}_{2}, \text { ref }}}\right) \exp \left[-\frac{E_{C, \phi_{0}}}{R}\left(\frac{1}{T}-\frac{1}{T_{\text {ref }}}\right)\right] i_{C, 0, \text { ref }}^{*}$

Similarly, the cathode limiting current is:

$i_{C, L} \equiv\left(\frac{v_{C e^{-}}}{-v_{C, O_{2}}}\right) \frac{F}{R T} P_{O_{2} E} \cdot p_{O_{2} S}$

where $p_{O 2 S}$ is the oxygen partial pressure in the cathode graphite plate, and $P_{O 2 E}$ is the permeability of cathodic gas diffusion layer for oxygen.

For both the anode and the cathode, $\gamma_{M}=a_{C} L_{c}$ where $a_{c}$ is the catalyst specific area (state-of-the-art catalyst has about 600 $1000 \mathrm{~cm}^{2} / \mathrm{mg}$ ), and $L_{c}$ is the catalyst loading (state-of-the-art electrodes have $0.3-0.5 \mathrm{mg} \mathrm{Pt} / \mathrm{cm}^{2}$, lower loadings are possible but would result in lower cell voltages) [31].

Moreover, the general expression of the permeability of a layer $\alpha$ for the species $i$ is,

$P_{i \alpha} \equiv \kappa_{i \alpha} D_{i \alpha} / L_{\alpha}$

where $K_{i \alpha}$ is the partition coefficient for species $i$ in layer $\alpha$, $D_{i \alpha}$ is the diffusion coefficient of species $i$ in layer $\alpha$, and $L_{\alpha}$ is the thickness of layer $\alpha$.

Hence, the fuel cell voltage can be expressed as follows,

$$
\begin{aligned}
V_{\text {cell }} & =V_{0}-\frac{R T}{\vec{\alpha}_{A} F} \sinh ^{-1}\left\{\frac{1}{2}\left(\frac{i / i_{A, 0}}{1-i / i_{A, L}}\right)\right\} \\
& -\frac{R T}{\vec{\alpha}_{C} F} \sinh ^{-1}\left\{\frac{1}{2}\left(\frac{i / i_{C, 0}}{1-i / i_{C, L}}\right)\right\}-i \cdot \frac{L_{m}}{\sigma_{m}}-i \cdot R_{I}
\end{aligned}
$$

The output voltage depends on partial pressures of reactants through anode and cathode over-potentials. Thus, in transient mode, this voltage will be influenced by the dynamics of these partial pressures. More precisely these variables are mainly 
affected by the anode and cathode volumes, and the air compressor dynamics. The next section will demonstrate the important role of these two reasons in the occurrence of hysteresis effect in the fuel cell output characteristic.

\subsection{Fuel cell dynamical model}

The previous paragraph underlined that the hydrogen and oxygen effective partial pressures are two key variables. Consequently, it is crucial to compute them precisely through the conservation principle.

First, the ideal gas law and the principle of molar conservation permit to deduce the following differential equations:

$$
\begin{aligned}
& \frac{d p_{\mathrm{O}_{2}}}{d t}=\frac{R T}{M_{\mathrm{O}_{2}} V_{c a}}\left(W_{\mathrm{O}_{2}, \text { in }}-W_{\mathrm{O}_{2}, \text { out }}-W_{\mathrm{O}_{2}, \text { rct }}\right) \\
& \frac{d p_{N_{2}}}{d t}=\frac{R T}{M_{\mathrm{N}_{2}} V_{c a}}\left(W_{N_{2}, \text { in }}-W_{\mathrm{N}_{2}, \text { out }}\right) \\
& \frac{d p_{\mathrm{H}_{2}}}{d t}=\frac{R T}{M_{\mathrm{H}_{2}} V_{a n}}\left(W_{\mathrm{H}_{2}, \text { in }}-W_{\mathrm{H}_{2}, \text { rct }}\right)
\end{aligned}
$$

In these equations, the inlet flow rates are expressed by:

$$
\begin{aligned}
& W_{\mathrm{O}_{2}, \text { in }}=\frac{x_{\mathrm{O}_{2}, a t m}}{1+\omega_{c a, i n}} W_{c a, i n} \\
& W_{N_{2}, \text { in }}=\frac{1-x_{\mathrm{O}_{2}, a t m}}{1+\omega_{c a, i n}} W_{c a, i n} \\
& W_{\mathrm{H}_{2}, \text { in }}=\frac{1}{1+\omega_{a n, i n}} W_{a n, i n}
\end{aligned}
$$

The reacted hydrogen and oxygen flows are related to the stack current and the cell number as follows:

$$
\begin{aligned}
W_{\mathrm{O}_{2}, r c t} & =M_{\mathrm{O}_{2}} \frac{N I_{F C}}{4 F} \\
W_{\mathrm{H}_{2}, r c t} & =M_{H_{2}} \frac{N I_{F C}}{2 F}
\end{aligned}
$$

Furthermore, as a result of hydrogen and oxygen consumption, the different output mass flow rates become dependent on the partial pressures as follows:

$$
\begin{aligned}
W_{\mathrm{O}_{2}, \text { out }} & =\frac{M_{\mathrm{O}_{2}} p_{\mathrm{O}_{2}}}{M_{\mathrm{O}_{2}} p_{\mathrm{O}_{2}}+M_{\mathrm{N}_{2}} p_{\mathrm{N}_{2}}+M_{v} p_{\text {sat }}} W_{\text {ca out }} \\
W_{\mathrm{N}_{2} \text {, out }} & =\frac{M_{\mathrm{N}_{2}} p_{\mathrm{N}_{2}}}{M_{\mathrm{O}_{2}} p_{\mathrm{O}_{2}}+M_{\mathrm{N}_{2}} p_{\mathrm{N}_{2}}+M_{v} p_{\text {sat }}} W_{\text {ca,out }} \\
W_{\mathrm{H}_{2}, \text { out }} & =\frac{M_{\mathrm{H}_{2}} p_{\mathrm{H}_{2}}}{M_{\mathrm{H}_{2}} p_{\mathrm{H}_{2}}+M_{v} p_{\text {sat }}} W_{\text {an, out }}
\end{aligned}
$$

Next, the inlet air flow $W_{c a, \text { in }}$ is calculated as follows:

$$
W_{c a, i n}=k_{c a, i n}\left(p_{s m}-p_{c a}\right)
$$

Where, $k_{c a, i n}$ is the orifice flow constant of the pipes, $p_{s m}$ is the air pressure in the supply manifold, and $p_{c a}$ is the total air pressure inside the cathode. In this expression, the air pressure $p_{s m}$ in the pipes between the compressor and the cathode inlet has the following dynamics:

$\frac{d p_{s m}}{d t}=\frac{R T_{c p}}{M_{a, a t m} V_{s m}}\left(W_{c p}-W_{c a, i n}\right)$

And, the cathode air pressure is the sum of the partial pressures of oxygen, nitrogen, and vapour:

$p_{c a}=p_{\mathrm{O}_{2}}+p_{N_{2}}+p_{\text {vap }}$

We consider that the air is saturated with water to $100 \%$, and then $p_{\text {vap }}$ is equal to $p_{\text {sat }}$ that depends on the temperature of the gaz.

Last, the outlet air flow $W_{\text {ca,out }}$ is calculated as follows:

$W_{\text {ca,out }}=k_{\text {ca,out }}\left(p_{c a}-p_{\text {atm }}\right)$

The air supply system, feeding the fuel cell with oxygen, is a mechanical system composed of a motor driving a compressor. Hence, the desired compressor air flow $W_{c p}$ is supplied to the fuel cell with a delay, depending on the dynamics of the used moto-compressor mechanical system. That will be a major factor in the hysteresis phenomenon, and it will be explained in the next section.

For simplicity's sake, and being interested by the global behaviour of the moto-compressor without entering in the details (open loop dynamics, controller dynamics, etc.) of this subsystem, we consider the latter as a first order filter that represents the delay for supplying the fuel cell with the desired air flow. This assumption will be argued in the next section.

Finally, the dynamic expressions of the output voltage, in (1)(18), show that the free Gibbs energy, and the cathode and anode overpotentials (due to activation and concentration losses), depend on the reactant partial pressures and the current density. Since temperature and relative humidity are assumed to be well regulated in the following simulations, ohmic losses depend on current density only. Thus, given the dynamics of the oxygen and hydrogen pressures inside the cathode and anode volumes, in (19) and (21), and the dynamics of the moto-compressor, the transient output characteristic presents some hysteresis, when the load current changes sinusoidally. The hysteresis curve shape clearly depends on the input frequency.

\section{Simulation Test}

Some results of the dynamic behaviour of the tested PEM fuel cell stack are presented in this section. Precisely, some analyses of the PEMFC parameters on the hysteresis effects are presented:

- Effect of the current demand frequency

- Effect in different polarization zones of losses 
- Effect of the compressor time constant

- Effect of the cathode volume

\subsection{Simulated PEMFC}

All simulations are performed under the MATLAB-Simulink environment. In these simulations, we consider a PEM fuel cell stack with an active cell area of $A_{F C}=280 \mathrm{~cm}^{2}$ and 381 cells, with $75 \mathrm{~kW}$ gross power output that is applicable for automotive and residential use [29]. Depending on the current drawn from the FC and the air supply of the FC, the stack voltage varies and is still limited to $350 \mathrm{~V}$. The maximum FC current is defined as the current at which the maximum FC power is achieved, and corresponds to $I_{F C \text {,max }}=320 \mathrm{~A}$. The air is supplied by a compressor that is driven by a motor with a maximum power of $15 \mathrm{~kW}$. At its maximum rotational speed of $100 \mathrm{kRPM}$, the compressor provides $95 \mathrm{~g} / \mathrm{sec}$ of air flow and generates a pressure increase of $3.5 \mathrm{~atm}$. In a previous work on the same fuel cell system [23], it has been demonstrated that the controlled compressor behaves as a first order filter with a time response equal to $1.5 \mathrm{sec}$. Then, a corresponding $1^{\text {st }}$ order filter is used to represent the compressor dynamics in the simulations.

Given that the compressor consumes up to $20 \%$ of the FC power, the net power delivered to the load can decrease enormously. Indeed, the compressor motor is electrically fed by the fuel cell itself. The work presented in [34] shows that the optimal net power delivered to the load corresponds to an oxygen stoechiometry equal to two $\left(\lambda_{\mathrm{O} 2}=2\right)$. That means that the compressor feeds the $\mathrm{FC}$ with oxygen twice the reactions request. Hence, the control aims to regulate the compressor air flow to the desired value, calculated by taking the latter constraint into account. The temperature of the FC stack is supposed constant at $\mathrm{T}=80^{\circ} \mathrm{C}$. The input gases are supposed fully humidified to $100 \%$ without water condensation inside the circulation pipes.

\subsection{Effect of the current demand frequency}

Figure 4 shows the static operating mode in dotted line. The simulations are performed using a sinusoidal load current between $0 \mathrm{~A}$ and $260 \mathrm{~A}$. Moreover, a hysteresis phenomenon takes place, even for relatively low frequencies of the current. This frequency limit depends on the parameters of the used FC essentially (cathode and anode volumes, etc.) and the moto-compressor time response. As can be seen in figures 4-a and 4-b, for low frequencies the hysteresis is anti-clockwise. Indeed, the increase of current causes instantaneously voltage drops, the flow of reacted oxygen increases, and then the oxygen stoechiometry decreases. The recovery time depends on the moto-compressor time response and on the amount of the air contained in the cathode bipolar plate, hence cathode volume. The hysteresis width increases with frequency until some limit, where it becomes impossible for the system to follow the load demand, because of its slower dynamics. Figure 4-c shows that at some frequency, the hysteresis width is reduced, but an " 8 " curve appears starting from low current densities, where the upper side of the " 8 " turns clockwise while the lower side rotates anti-clockwise. The upper side becomes more and more significant with the increase of the frequency. At higher frequencies, this upper side dominates the global behaviour and the hysteresis changes direction by rotating clockwise (Fig.4-d). This behaviour is not acceptable, it shows that the system cannot provide the needed power and the compressor response is delayed enormously.

The observation of the "8" curve rotation is an important element, proving that, when the temperature and humidity are regulated, the hysteresis is mainly due to the air supply system dynamics and geometry. Indeed, the mentioned result is in opposition to the one obtained when the water accumulation effect is considered alone. As can be observed in [36] and [37] and [22], when an "8" effect - due to an excess of liquid water - appears between forward and backward current scans, it starts in high current densities range. Moreover, the upper side (for low current densities) of the " 8 " turns anti-clockwise when the lower side (for high current densities) rotates clockwise, in opposition to our result. Both phenomena (water management and compressor dynamics) have interpretation, proving that both of them take place inside the fuel cell, influence the dynamic behaviour, and should be considered.

As mentioned in [22], "when a cell is flooding, the downward $\mathrm{I}-\mathrm{V}$ curve would show lower voltages than upward I-V curve at high current densities. This is due to the increase of liquid water content in the electrode as additional water is produced by the growing current density. Conversely, if the cell is drying, production of additional water at high current densities is "welcome" and would result in higher potential". In the latter case, there is no " 8 " effect.

However, when the water content is regulated around a constant value, the phenomenon causing the " 8 " curve is totally different.

When frequency increases, the compressor air flow $W_{c p}$ range becomes narrower, with lower maxima and higher minima (Fig.5). Arriving to low current densities with higher minimum of air flow leads to an accumulation of stocked air in the cathode pipes volume. This air reserve still increasing until a new consumption cycle. Due to the stocked air in the pipes, the voltage losses tend to decrease in time between backward and forward current scan, inducing an "8" effect with an upper side rotating clockwise in low current density range. However, in high current density range, the maximum air flow is lower than needed, inducing more losses. As long as the compressor air flow can recover with a small time delay, the hysteresis rotates anti-clockwise in this region (Fig.4-c). When frequency increases, the compressor response is delayed enormously and the air flow amplitude is reduced. During the transition from forward to backward current scan, the reactant consumption is very high; even the maximum air flow at that frequency cannot compensate the lack of reactant. Hence, the voltage losses tend to increase in time in this region, and the hysteresis rotates clockwise. The "8" disappears (Fig.4-d).

Figure 5 shows the compressor air flow $W_{c p}$ and the oxygen partial pressure $p_{O 2}$, over one period. For relatively low frequencies of about $0.1 \mathrm{~Hz}$ (Fig.5-a), a small delay can be 
noticed between $W_{c p}$ and the current density $i$. A larger delay can be observed between $p_{O 2}$ and the current density $i$. The delay between $W_{c p}$ and $i$ increases according to the rising frequency while amplitude of $W_{c p}$ decreases. Indeed, the current frequency goes over the compressor frequency bandwidth. At a $1 \mathrm{~Hz}$ current frequency, the compressor flow becomes almost constant around the mean value. Furthermore, the delay between the partial pressure $p_{O 2}$, whose dynamics depend on the cathode volume, and the current density $i$ increases enormously. At $\mathrm{f}=0.1 \mathrm{~Hz}$ (anti-clockwise rotation), $p_{O 2}$ has a negative time delay compared to $i$; for $\mathrm{f}=0.5 \mathrm{~Hz}$ ("8" effect), it is almost in opposition of phase with $i$; and at $\mathrm{f}=1 \mathrm{~Hz}$ (clockwise rotation), $p_{O 2}$ has a positive time delay with $i$. So, the rotation sense of the hysteresis is influenced by this time delay. Hence, at $1 \mathrm{~Hz}$, it is clear that the dynamics of the system becomes significantly slower than the current demand.

Moreover, Figure 4 shows that, for high current densities, the concentration voltage drop increases with frequency rising. Caused by the different air supply dynamics (motocompressor, cathode volume, etc.) the phase-shift between partial pressure and current gradually moves from $0^{\circ}$ to almost $-180^{\circ}$. As a result, the reactant concentration becomes low at high current densities, inducing this large voltage drop. Conversely, the reactant pressures grow to a high level at low current densities, producing a small voltage drop.
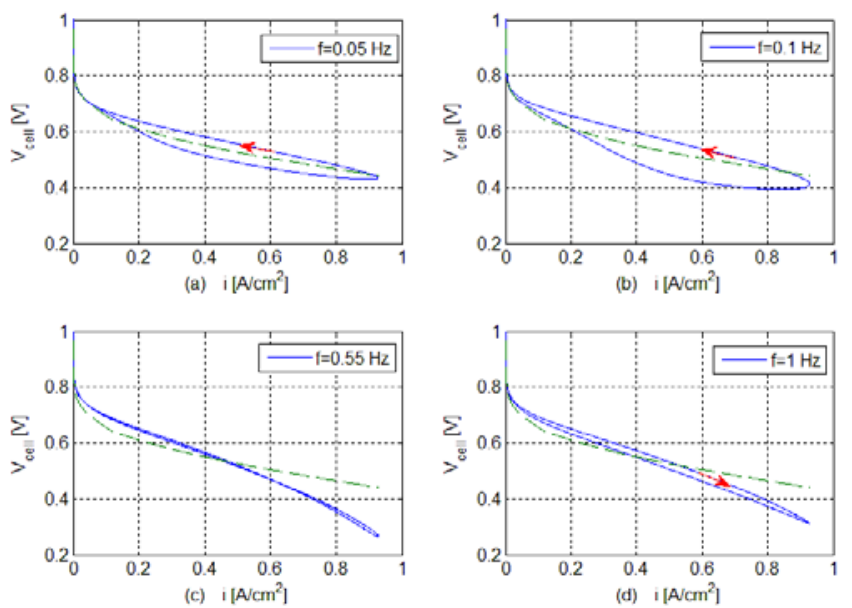

Fig. 4. Hysteresis effect at different current frequencies

Figure 5 shows the time responses of the compressor air flow $W_{c p}$ and oxygen partial pressure $p_{O 2}$, at different frequencies of the load current variation.
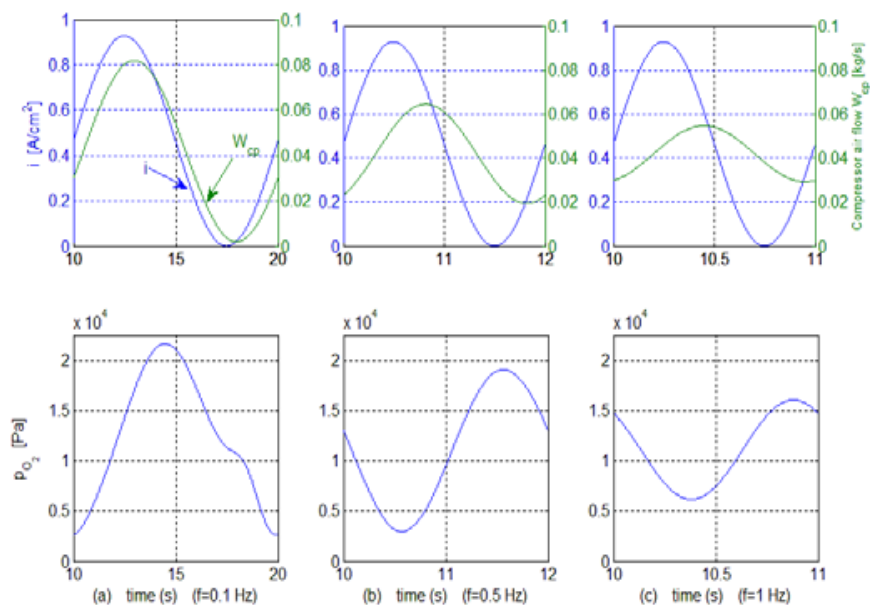

Fig. 5. Time responses of $W_{c p}$ and $p_{O 2}$.

\subsection{Effect in different polarization zones of losses}

The thickness of the hysteresis depends on the current density zone and the amplitude of current demand (Fig. 6).

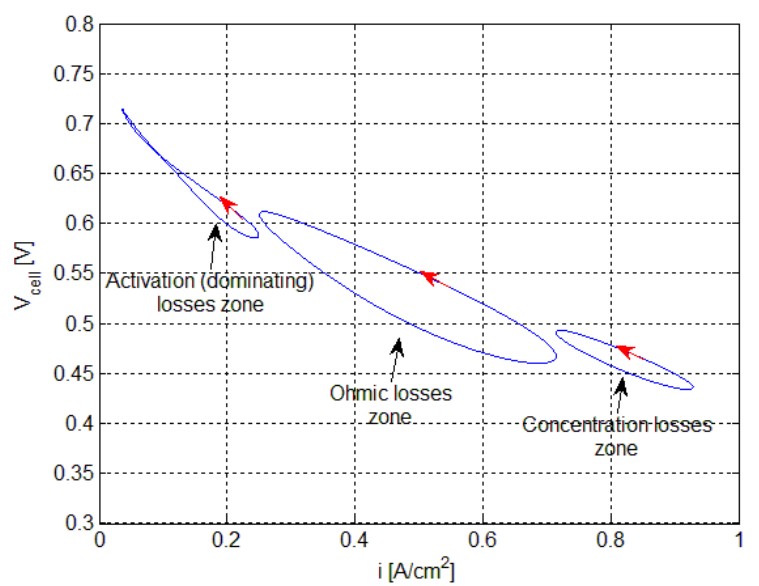

Fig. 6. Hysteresis effect with a $0.1 \mathrm{~Hz}$ sinusoidal load current

First, in the zone where activation losses are predominant, an "8" effect appears at $0.1 \mathrm{~Hz}$. The hysteresis is thin, because the stored air of the cathode volume is important owing to the low current demand in this region. Subsequently, the available air is sufficient to prevent oxygen starvation.

Second, even if ohmic losses don't depend on the reactant partial pressures, a significant hysteresis effect appears in the ohmic zone. As a matter of fact the Gibbs free energy and the activation losses influence the entire current domain and are strongly affected by the reactant concentrations.

Finally, Figure 6 shows that between two nearby cycles, an important step occurs. Indeed, the limiting current density between both of them represents the upper limit in current for the left one and the lower limit in current for the right one. The left cycle upper limit is reached while the current increases; thus, the fuel cell is under-supplied due to the time delay of the air supply sub-system. Hence, the obtained voltage is lower than the steady state voltage. 
On the other hand, the right cycle lower limit is hit when the current decreases; consequently, the fuel cell is over-supplied, also due to the air supply time delay. Hence, the obtained voltage is higher than the steady state one.

Summarizing, the left cycle is under-supplied (less voltage) and the right one is over-supplied (higher voltage); subsequently a step-up appears between both nearby hysteresis.

\subsection{Effect of the compressor time constant}

Figure 7 presents the hysteresis cycle for different compressor time constants $\tau_{\text {comp }}$, with the same current frequency of $0.1 \mathrm{~Hz}$ and the same cathode volume $V_{c a}$ of $0.01 \mathrm{~m}^{3}$. When the compressor dynamics becomes slower (higher time constant), the hysteresis thickness increases, and the voltage drop at high current density becomes more important. Moreover, Fig. 7-c shows that the compressor time response of about $3 \mathrm{~s}\left(3 \tau_{\text {comp }}\right)$ becomes inadequate and causes a stack starvation.
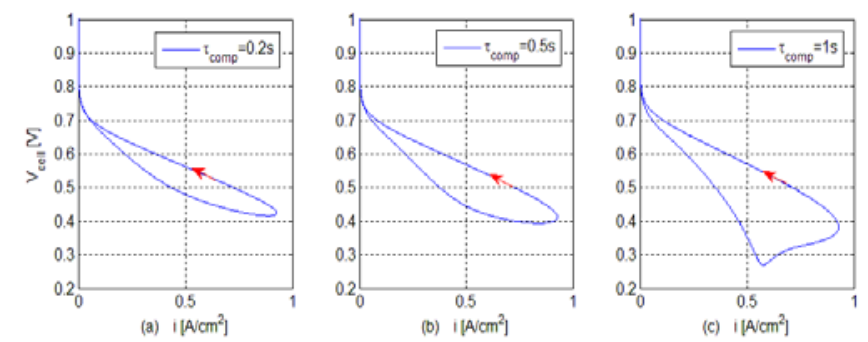

Fig. 7. Hysteresis effect for various compressor time constant

\subsection{Effect of the cathode volume}

Figures 8 and 9 show the hysteresis cycle for different cathode volumes $\mathrm{V}_{\text {ca }}$, with a $0.1 \mathrm{~Hz}$ current frequency and a $0.5 \mathrm{~s}$ compressor time constant. When increasing the cathode volume, the hysteresis thickness decreases. Indeed, it is due to the important reserve of air present in the bigger cathode volume, and so preventing stack starvation. However, the voltage drop at high current densities increases. Indeed, once the available stored air is consumed to feed the load, the compressor air flux increases and slowly refills the cathode volume with air. This effect is more important when this volume is bigger; this fact causes a more important voltage drop.

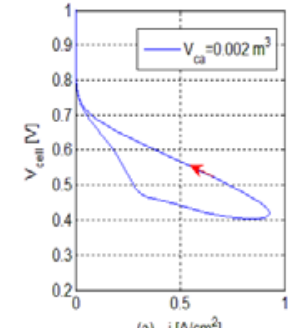

(a) $\mathrm{i}\left[\mathrm{Acm}^{2}\right]$

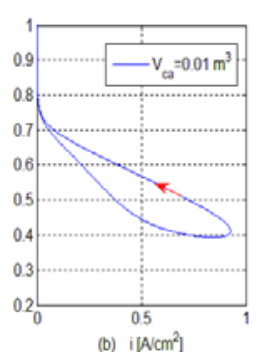

(b) i $\left[\mathrm{Acm}^{2}\right]$

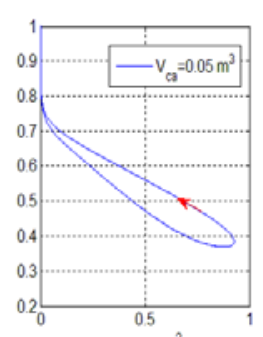

(c) $i\left[\mathrm{Acm}^{2}\right]$
Fig. 8. Hysteresis effect for different cathode volumes $V_{c a}$

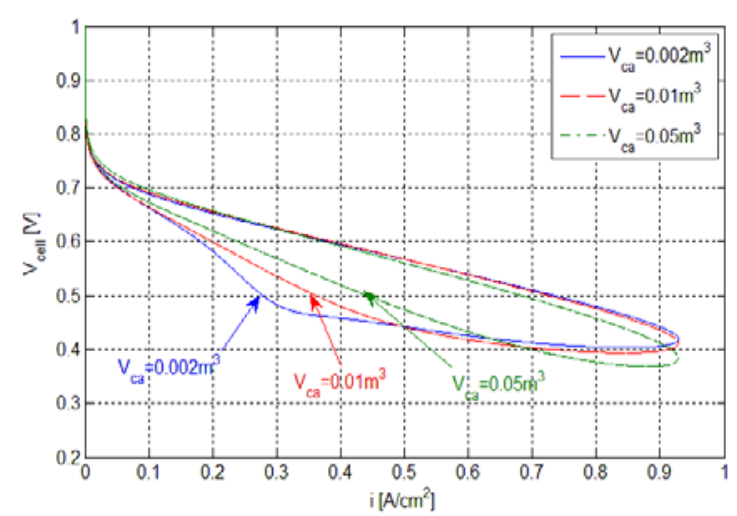

Fig. 9. Superposition of Figure 8 curves

\section{Experimental Results}

In this section, some experimental results on a Ballard fuel cell generator are presented in order to validate the reasons of such hysteresis phenomena and to confirm the most important parameters that influence the occurrence and the form of this cycle.

\subsection{Test Bench description}

To validate the different effects analysed with the previous model experimental tests were performed on a Nexa BALLARD PEMFC generator. This system consists in an air cooled stack monitored with an internal processor. The stack is composed of $n=46$ cells in series with an active area of $\mathrm{A}_{\mathrm{FC}}=110 \mathrm{~cm}^{2}$. It has a nominal power of $1200 \mathrm{~W}$ related to a rated current of $i_{\text {nom }}=46 \mathrm{~A}$ and a rated output voltage of $\mathrm{V}_{\text {nom }}=26 \mathrm{~V}$. The compressor time response is about $1.5 \mathrm{~s}$. Dynamical model parameters of the Nexa Ballard PEM fuel cell are taken from [40]. Data measurements were done by a real-time dSPACE DS1104 controller board through the A/D converters mounted on an interfacing card, with a sampling frequency of $25 \mathrm{kHz}$. The load profile is emulated with a programmable electronic load (Höcherl \& Hackl, model ZS1806), which has a rated power of $1800 \mathrm{~W}\left(\mathrm{i}_{\max }=150 \mathrm{~A} /\right.$ $\mathrm{V}_{\max }=60 \mathrm{~V}$ ). The experimental environment is shown in Figure 10.

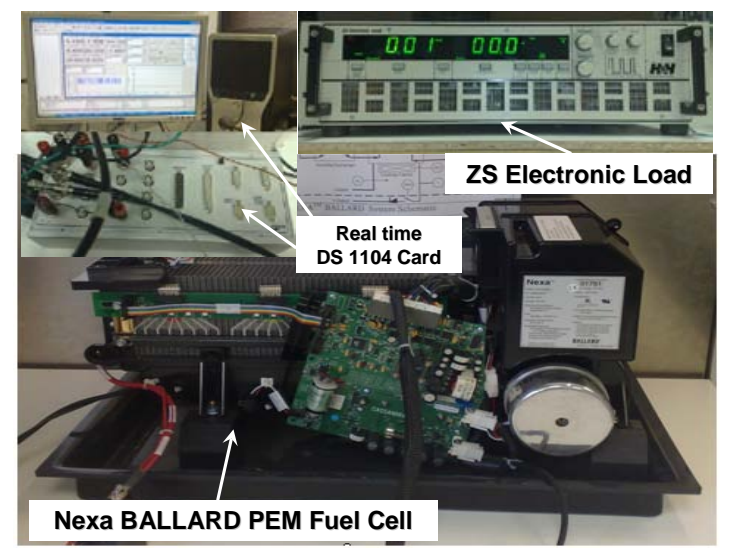

Fig. 10. The components of the experimental bench. 


\subsection{Results Analyses}

The experiments have been carried out by measuring the output voltage, when a sinusoidal load current demand is applied to the fuel cell, at different frequencies.

First, the experimental data have been compared to the simulation results of the physical model. As shown in Fig. 11, the implemented model estimates the stack voltage with a good accuracy. It approximates well the average global voltage and predicts properly the hysteresis cycle that occurs in the output characteristic, voltage versus current plot.

Then, with a stack temperature fixed at $45^{\circ} \mathrm{C}$, V-I characteristics are depicted at different frequencies ranging from $0.01 \mathrm{~Hz}$ to $0.4 \mathrm{~Hz}$ (fig. 12). As explained in the simulation tests section, the width and the form of the hysteresis cycle depend essentially on the current frequency, the geometrical size of the air supply and the time response of the air compressor. At small frequency, the hysteresis cycle is thick and anti-clockwise. While frequency increases, it becomes thinner with an "8 effect" occurring first at low current densities then at high current densities. When this "8 effect" completely disappears the hysteresis effect is clockwise and becomes thicker. The rotation of the " 8 " curve in experimental results validates our simulation results, what proves that the air system dynamics is the main reason for hysteresis, given that the Nexa Ballard fuel cell is equipped with a passive humidifier that regulates humidity.

Finally a small magnitude sinusoidal waveform is performed in the ohmic region where the FC generator achieves good efficiency performs (fig. 13). This experiment demonstrates that at high frequencies (compared to compressor bandwidth) the global stack voltage is lower than the quasi-static stack response. This is due to partial stack starvation and proves that a hybrid structure is relevant to enhance both PEMFC generator efficiency and stack lifetime [10], [12].

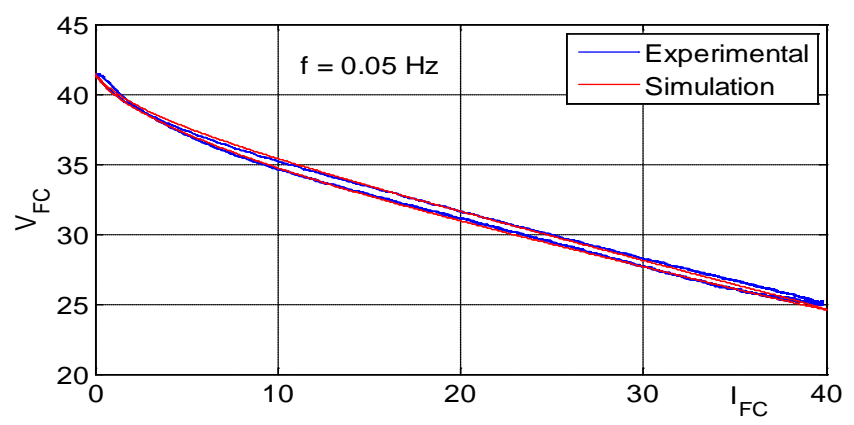

Fig. 11. Comparison of experimental results and simulations computations at a temperature of $\mathrm{T}=45^{\circ} \mathrm{C}$, and a frequency of $\mathrm{f}=0.05 \mathrm{~Hz}$.
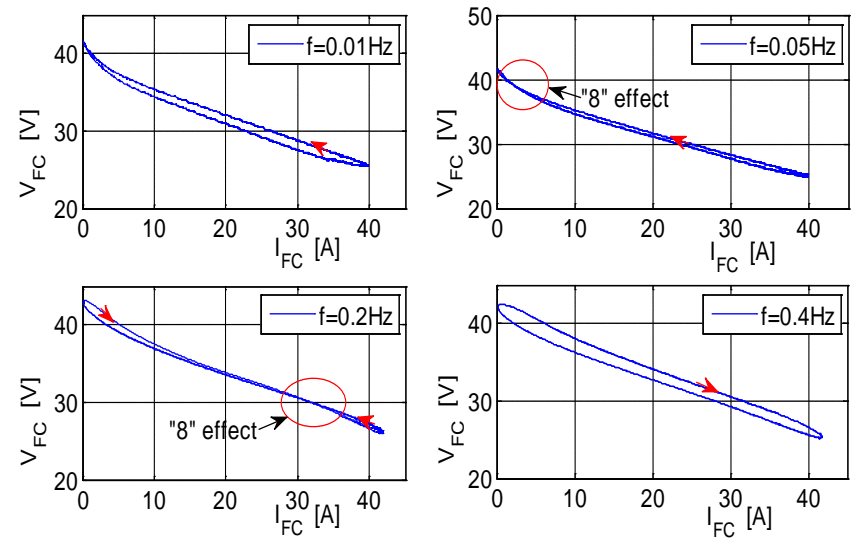

Fig. 12. Experimental results at a temperature of $\mathrm{T}=45^{\circ} \mathrm{C}$,

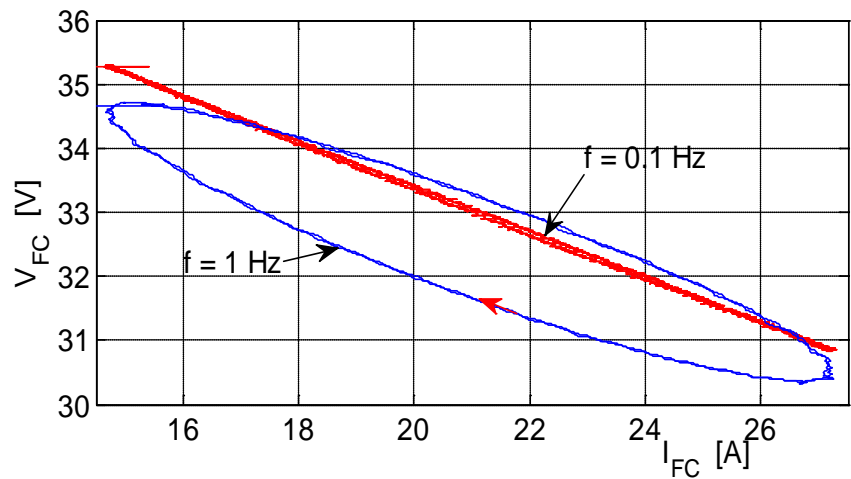

Fig. 13. Experimental results at a temperature of $\mathrm{T}=45^{\circ} \mathrm{C}$, with small sinusoidal magnitude

In summary, the simulation results fit the experimental curve well; it validates the applied dynamical model which proves that it represents the real system well. Given that the model is simulated at a fixed temperature, and fully humidified gases (fixed relative humidity), we can conclude that the hysteresis is essentially due to the compressor dynamics and the oxygen partial pressure dynamics, the latter being influenced by the cathode volume. This result is consistent with the analytical study presented in section 4 , which is based on simulations.

Hence, we can conclude that, for controlled humidity degree and temperature, the variables responsible for the hysteresis, and which have a dominating role on its shape, are particularly the frequency, the compressor time response, and the cathode volume.

\section{Conclusion}

In this paper, a dynamical PEMFC model has been presented and implemented in Matlab-Simulink environnement. It allows us to understand the hysteresis effect observed on FC systems while the load is fluctuating. Indeed, simulations underline that the major parameters involved in this phenomenon are those of the air supply; namely, the air compressor time response, the gas channel geometry, the gas distribution plate and GDL materials. Moreover, although temperature and humidity conditions affect stack electric performance, they have little effect on the system since these variables are controlled and vary slowly compared to load 
current. Finally, the model simulation results have been successfully qualitatively compared with the experimental results obtained on a Ballard NEXA $1.2 \mathrm{~kW}$ PEMFC system.

This work allows us to point out the key parameters that limit PEMFC system electric in its functioning. In addition, the implemented model can be used for real time applications. Hence, the perspective of this study is to determine the best hybridization architecture for a given specification. Then, for each application, the objective will be to optimize both the primary source (FC) and the storage device (auxiliary source) to enhance a FC feeding. The key criteria of this optimization process could be size, cost and efficiency.

\section{References}

[1] J. Larminie, A. Dicks, Fuel cell systems explained, John Wiley \& Sons, 2nd ed., 2003.

[2] F.H.Sobrino, C.R. Monroy, J.L.H. Pérez, "Critical analysis on hydrogen as an alternative to fossil fuels and biofuels for vehicles in Europe", Renewable and Sustainable Energy Reviews, Vol.14, No.2, Feb. 2010, pp.772-780.

[3] P. Fontela, A. Soria, and all, “Airport electric vehicle powered by fuel cell”, Elsevier, Journal of Power Sources, Vol. 169, 2007, pp.184-193.

[4] A. Kirubakaran, S. Jain, R.K. Nema, "A review on fuel cell technologies and power electronic interface”, Renewable and Sustainable Energy Reviews, Vol.13, No.9, Dec.2009, pp. 2430-2440.

[5] B. Gou, W.K. Na, B. Diong, Fuel Cells-Modeling, Control, and Applications, Taylor \& Francis, Aug. 2009.

[6] K. Kordesch, G. Simander, Fuel Cells and Their Applications, Wiley-VCH, 1996.

[7] M. Gerard, J-P. Poirot-Crouvezier, P. Schott, A.A. Franco, "PEMFC fuel cell/system interaction: analysis of the stack condition to minimize the oxygen starvation and impact on the fuel cell degradation performance”, Fundamentals and Developments of Fuel Cells Conference, FDFC2008, Nancy, France, 2008.

[8] S.D. Knights, K. M. Colbow, J. St-Pierre, and D.P. Wilkinson, "Aging mechanisms and lifetime of PEFC and DMFC”, J. of Power Sources, Vol. 127, 2004, pp. 127-134.

[9] A. Taniguchi, T. Akita, K. Yasuda and Y. Miyazaki, "Analysis of electrocatalyst degradation in PEMFC caused by cell reversal during fuel starvation”, J. of Power Sources, Vol.130, 2004, pp. 42-49.

[10] T. Azib, O. Bethoux, C. Marchand, and E. Berthelot, "Supercapacitors for Power Assistance in Hybrid Power Source with Fuel Cell", 35th Annual Conference of the IEEE Industrial Electronics Society, IEEE-IECON, Porto, Portugal, Nov. 2010

[11] N. Yousfi-Steiner, Ph. Moçotéguy, D. Candusso, D. Hissel, "A review on polymer electrolyte membrane fuel cell catalyst degradation and starvation issues: Causes, consequences and diagnostic for mitigation", J. of Power Sources, Vol. 194, 2009, pp. 130-145

[12] B. Wahdame, D. Candusso, X. François, F. Harel, M-C. Péra, D. Hissel, J-M. Kauffmann, “Comparison between two PEM fuel cell durability tests performed at constant current and under solicitations linked to transport mission profile”, Int. J. of Hydrogen Energy, Vol. 32, No.17, Dec. 2007, pp. 4523-4536.

[13] B. Davat, S. Astier, T. Azib, O. Bethoux, D. Candusso, G. Coquery, A. De Bernardinis, F. Druart, B. François, M. Garcia Arregui, F. Harel, D. Hissel, J-P. Martin, M-C. Péra, S. Pierfederici, S. Raël, D. Riu, S. Sailler, Y. Bultel, T. Creuzet, C. Turpin and T. Zhou, "Fuel cell-based hybrid systems”, ELECTROMOTION, 1-3 July, 2009 , Lille, France.

[14] T. Azib, O. Bethoux, G. Remy, C. Marchand, and E. Berthelot, "An Innovative Control Strategy of a Single Converter for Hybrid Fuel Cell/Supercapacitors Power Source", IEEE Trans. on Industrial Electronics, 2010 (in press).

[15] G. Fontes, C. Turpin, S. Astier, T.A. Meynard, "Interactions Between Fuel Cells and Power Converters: Influence of Current Harmonics on a Fuel Cell Stack", IEEE Trans. on Power Electronics, Vol. 22, No.2, 2007, pp. 670678.

[16] G. Fontes, C. Turpin, S. Astier, "A Large-Signal and Dynamic Circuit Model of a PEM Fuel Cell: Description, Parameter Identification, and Exploitation", IEEE Trans. on Industrial Electronics, Vol. 57, No.6, 2010, pp. 1874-1881.

[17] T. Azib, O. Bethoux, G. Remy, C. Marchand, "Structure and Control Strategy for a Parallel Hybrid Fuel Cell/Supercapacitors Power Source ", The 5th IEEE Vehicle Power and Propulsion Conference, IEEE-VPPC 2009, Dearborn, USA, Sept. 2009.

[18] J. Larminie, J. Lowry, Electric Vehicle Technology Explained, Wiley, Dec. 2003

[19] P. Thounthong, V. Chunkag, P. Sethakul, B. Davat, M. Hinaje, "Comparative Study of Fuel-Cell Vehicle Hybridization with Battery or Supercapacitor Storage Device”, IEEE Transactions on Vehicular Technology, Vol. 58, No.8, Oct. 2009, pp. 3892-3904.

[20] F. Barbir, PEM Fuel Cells: Theory and Practice, Elsevier Academic Press, New York, 2005.

[21] V. A. Lysenko, "Current trends in the design of gasdiffusion layers for fuel cells," Fibre Chemistry, Vol. 40, No.3, May 2008, pp. 226-233.

[22] N. Yousfi-Steiner, Ph. Moçotéguy, D. Candusso, D. Hissel, A. Hernandez and A. Aslanides, "A review on PEM voltage degradation associated with water management: Impacts, influent factors and characterization," Journal of Power Sources, Vol. 183, No.1, Aug. 2008, pp. 260-274. 
[23] R.J. Talj, D. Hissel, R. Ortega, M. Becherif, M. Hilairet, "Experimental validation of a PEM fuel-cell reduced-order model and a moto-compressor higher order sliding-mode control”, IEEE Trans. on Industrial Electronics, Vol. 57, No.6, 2010, pp. 1906-1913.

[24] F. Gao; B. Blunier; A. Miraoui,A. El Moudni, “A Multiphysic Dynamic 1-D Model of a Proton-ExchangeMembrane Fuel-Cell Stack for Real-Time Simulation”, IEEE Transactions on Industrial Electronics, Vol. 57, No.6, Jun. 2010, pp. 1853-1864 (in press).

[25] M. Sahraoui, C. Kharrat, K. Halouani, “Twodimensional modeling of electrochemical and transport phenomena in the porous structures of a PEMFC", Int. J. of Hydrogen Energy, Vol. 34, No.7, Apr. 2009, pp.3091-3103

[26] H.H. Lin, C.H. Cheng, C.Y. Soong, F. Chen, W.M. Yan, "Optimization of key parameters in the proton exchange membrane fuel cell”, J. of Power Sources, Vol. 162, No.1, Nov. 2006, pp. 246-254

[27] A. Esposito, C. Pianese, Y.G. Guezennec, "Coupled modeling of water transport and air-droplet interaction in the electrode of a proton exchange membrane fuel cell”, $J$. of Power Sources, Vol. 195, No.13, Jul. 2010, pp. 4149-4159

[28] M. Najjari, F. Khemili, S. Ben Nasrallah, "The effects of the cathode flooding on the transient responses of a PEM fuel cell”, Renewable Energy, Vol. 33, No.8, Aug. 2008, pp.1824-1831. [27] J.T. Pukrushpan, A.G. Stefanopoulou, and H. Peng, Control of Fuel Cell Power Systems: Principles, Modeling, Analysis and Feedback design, Springer London, UK, 2004.

[29] T. Thampan, S. Malhotra, J. Zhang, R. Datta, "PEM fuel cell as a membrane reactor”, Catalysis Today, Elsevier, Vol. 67, 2001, pp. 15-32.

[30] T. Thampan, S. Malhotra, H. Tang, R. Datta, "Modeling of conductive transport in proton-exchange membranes for fuel cells”, J. of the Electrochemical Society, Vol. 147, No.9, 2000, pp. 3242-3250.

[31] S.A. Vilekar, R. Datta, “The effect of hydrogen crossover on open-circuit voltage in polymer electrolyte membrane fuel cells”, J. of Power Sources, Elsevier, Vol. 195, 2010, pp. 2241-2247.

[32] T.M. Thampan, "Design and development of higher temperature membranes for PEM fuel cells", Dissertation for the degree of Doctor of Philosophy, Faculty of the Worcester Polytechnic Institute, 2003.

[33] J.T. Pukrushpan, H. Peng, and A.G. Stefanopoulou, "Control-Oriented Modeling and Analysis for Automotive Fuel Cell Systems”, Trans. of the ASME, Vol.126, 2004, pp. 14-25.

[34] J.T. Pukrushpan, A.G. Stefanopoulou, and H. Peng, "Control of fuel cell power systems: principles, modeling, analysis and feedback design,” Springer, 2004.
[35] R. Saisset, G. Fontes, Ch. Turpin and S. Astier, "Bond Graph model of a PEM fuel cell,” Journal of Power Sources, Vol. 156, No.1, 19 May 2006, pp. 100-107.

[36] D. Gerteisen, T. Heilmann and Ch. Ziegler, "Modeling the phenomena of dehydration and flooding of a polymer electrolyte membrane fuel cell," Journal of Power Sources, Vol. 187, No.1, Feb. 2009, pp. 165-181.

[37] A.A. Shah, G.-S. Kim, P.C. Sui and D. Harvey, "Transient non-isothermal model of a polymer electrolyte fuel cell,” Journal of Power Sources, Vol. 163, No.2, Jan. 2007, pp. 793-806.

[38] M. Mikkola, "Experimental studies on polymer electrolyte membrane fuel cell stacks," Master's thesis submitted in partial fulfilment of the requirements for the degree of Master of Science in Technology, 2001. http://www.tkk.fi/Units/AES/studies/dis/mikkola.pdf

[39] J.-M. Le Canut, R. Latham, W. Mérida and D.A. Harrington, "Impedance study of membrane dehydration and compression in proton exchange membrane fuel cells," Journal of Power Sources, Vol. 192, No.2, Jul. 2009, pp. 457466.

[40] A.J. del Real, A. Arce and C. Bordons, "Development and experimental validation of a PEM fuel cell dynamic model," Journal of Power Sources, Vol. 173, No.1, Nov. 2007, pp. 310-324.

[41] L. Boulon, D. Hissel, A. Bouscayrol, M-C Pera, "From Modeling to Control of a PEM Fuel Cell Using Energetic Macroscopic Representation”, Industrial Electronics, IEEE Trans. on, Vol. 57 , No.6, 2010, pp. 1882-1891.

\section{@@@@}

[7][42] D. Cheddie, N. Munroe, "Review and comparison of approaches to proton exchange membrane fuel cell modelling,” J. of Power Sources, Vol.147, 2005, pp. 72-84.

[8][43] J.C. Amphlett and R.F. Mann et al., “A model predicting transient responses of proton exchange membrane fuel cells”, J. of Power Sources, Vol.61, 1996, pp. 183-188.

[9][44] J. Hamelin, K. Agbossou, A. Laperri.ere, F. Laurencelle, T.K. Bose, ”Dynamic behavior of a PEM fuel cell stack for stationary applications", Int. J. of Hydrogen Energy, Vol.26, 2001, pp. 625-629. 


\begin{tabular}{|c|c|c|c|}
\hline \multicolumn{4}{|c|}{ Nomenclature } \\
\hline$V_{F C}$ & Stack output voltage [V] & $A$ & Degree of acid group dissociation \\
\hline$V_{\text {cell }}$ & Cell voltage [V] & $\lambda$ & Water loading \\
\hline$N$ & Number of cells in stack & $K_{A, C}$ & $\begin{array}{l}\text { Equilibrium constant for proton solvation in terms of } \\
\text { concentrations }\end{array}$ \\
\hline$V_{0}$ & Cell open circuit voltage at standard pressure [V] & $4 H^{0}$ & \\
\hline$V_{C}$ & Cathodic overpotential [V] & $\Delta H^{\circ}$ & Enthalpy change for proton salvation [kJ/mol] \\
\hline$V_{A}$ & Anodic overpotential [V] & $\alpha_{A}$ & Effective transfer coefficient of overall anode reaction $=1 / 2$ \\
\hline$V_{m}$ & Ohmic losses [V] & $\alpha_{C}$ & Effective transfer coefficient of overall cathode reaction $=1$ \\
\hline$R_{I}$ & Interfacial resistance $\left[\Omega . \mathrm{m}^{2}\right]$ & $i_{A / C, 0}$ & Anodic/cathodic exchange current density $\left[\mathrm{A} / \mathrm{cm}^{2}\right]$ \\
\hline$R$ & Universal gas constant [bar. $\left.\mathrm{m}^{3} / \mathrm{mol} / \mathrm{K}\right]$ & $i_{A / C, L}$ & Anodic/cathodic limiting current density $\left[\mathrm{A} / \mathrm{cm}^{2}\right]$ \\
\hline$F$ & Faraday's constant [C/mol] & $\gamma_{M, A / C}$ & Roughness factor $\left[\mathrm{cm}^{2} \mathrm{Pt} / \mathrm{cm}^{2}\right.$ geometric electrode area] \\
\hline$T$ & Operating temperature [K] & $E_{A / C, \phi 0}$ & Effective activation energy of $i_{A / C, 0}[\mathrm{~kJ} / \mathrm{mol}]$ \\
\hline$T_{c p}$ & Air temperature at the output of the compressor [K] & $i^{*} A / C, 0$, ref & Reference anodic/cathodic exchange current density $\left[\mathrm{A} / \mathrm{cm}^{2}\right]$ \\
\hline$p_{H 2}$ & Partial pressure of hydrogen inside the anode [bar] or [Pa] & $v_{\rho, i}$ & Stoichiometric coefficient of species $i$ in reaction $\rho$ \\
\hline$p_{O 2}$ & Partial pressure of oxygen inside the cathode [bar] or [Pa] & $v_{\rho e-}$ & Stoichiometric coefficient of electrons in reaction $\rho$ \\
\hline$p_{N 2}$ & Partial pressure of nitrogen inside the cathode [Pa] & $P_{i \alpha}$ & Permeability of layer $\alpha$ for species $i$ \\
\hline$p_{\mathrm{H} 2 \mathrm{O}}$ & Pressure of liquid water [bar] & $\kappa_{i \alpha}$ & Partition coefficient of species $i$ in layer $\alpha$ \\
\hline$p_{\text {vap }}$ & Partial pressure of gas water in air $[\mathrm{Pa}]$ & $D_{i \alpha}$ & Diffusion coefficient of species $i$ in layer $\alpha$ \\
\hline$p_{c a}$ & Air pressure in the cathode [Pa] & $L_{\alpha}$ & Thickness of layer $\alpha$ \\
\hline$p_{a t m}$ & Atmospheric pressure [bar] or [Pa] & $W_{i, \text { in/out }}$ & $\begin{array}{l}\text { Mass flow rate of species } i \text { entering/leaving the cathode or the } \\
\text { anode }\end{array}$ \\
\hline$p_{\text {sat }}$ & Saturation pressure $[\mathrm{Pa}]$ & $W_{i, r c t}$ & Mass flow rate of reacted species $i$ \\
\hline$i$ & Current density of the PEM fuel cell $\left[\mathrm{A} / \mathrm{m}^{2}\right]$ & $W_{\text {ca in/out }}$ & Mass flow rate of air entering/leaving the cathode \\
\hline$I_{F C}$ & Current of the PEM fuel cell [A] & $W_{\text {an,in/out }}$ & Mass flow rate of gas entering/leaving the anode \\
\hline$A_{F C}$ & Active surface area of a cell $\left[\mathrm{m}^{2}\right]$ & $W_{c p}$ & Mass flow rate of the air leaving the compressor \\
\hline$\Delta G_{f}$ & Gibbs free energy of formation $[\mathrm{J} / \mathrm{mol}]$ & $M_{i}$ & Molar mass of species $i$ \\
\hline$L_{m}$ & Membrane thickness & $M_{v}$ & Vapor molar mass \\
\hline$\sigma_{m}$ & Membrane proton conductivity & $M_{a, a t m}$ & Molar mass of atmospheric air \\
\hline$\varepsilon_{m}$ & Membrane porosity & $V_{c a}$ & Cathode volume \\
\hline$\varepsilon_{m 0}$ & $\begin{array}{l}\text { Percolation threshold volume fraction of water in hydrated } \\
\text { membrane }\end{array}$ & $V_{a n}$ & Anode volume \\
\hline$q$ & Bruggeman or critical exponent $=1.5$ & $V_{s m}$ & Supply manifold volume \\
\hline$\lambda^{0}{ }_{H^{+}, 298}$ & $\begin{array}{l}\text { Equivalent conductance for } \mathrm{H}^{+} \text {at infinite dilution, at } \\
\text { reference temperature (298K) }\left[\mathrm{S} \mathrm{cm}^{2}\right]\end{array}$ & $\omega_{\mathrm{ca}, \mathrm{in}}$ & $\begin{array}{l}\text { Cathode inlet humidity ratio } \\
\text { Anode inlet humidity ratio }\end{array}$ \\
\hline$\delta$ & Ratio of mutual to matrix effective diffusion coefficients & $x_{02, \text { atm }}$ & Oxygen mass fraction \\
\hline$E_{\mu}$ & Activation energy for viscosity $[\mathrm{kJ} / \mathrm{mol}]$ & $k_{c a, \text { in/out }}$ & Inlet/outlet orifice flow constant of the cathode \\
\hline$C_{H A, 0}$ & Concentration of membrane acid groups $\left[\mathrm{mol} / \mathrm{cm}^{3}\right]$ & & \\
\hline
\end{tabular}

